\title{
The Legal Governance of Oil and Gas in Europe: An Indicator Analysis of the Implementation of the Hydrocarbons Directive
}

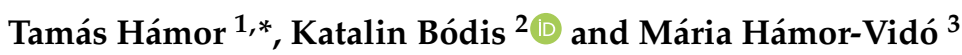 \\ 1 European Commission, Joint Research Centre, 21027 Ispra, Italy \\ 2 Institute of Advanced Studies, 9730 Kőszeg, Hungary; katalin.bodis@geography.hu \\ 3 Faculty of Sciences, University of Pécs, 7622 Pécs, Hungary; vido.maria@pte.hu \\ * Correspondence: tamas.hamor@ec.europa.eu
}

Citation: Hámor, T.; Bódis, K.;

Hámor-Vidó, M. The Legal

Governance of Oil and Gas in Europe:

An Indicator Analysis of the

Implementation of the Hydrocarbons

Directive. Energies 2021, 14, 6411.

https://doi.org/10.3390/en14196411

Academic Editor: Victor Manuel

Ferreira Moutinho

Received: 14 September 2021

Accepted: 2 October 2021

Published: 7 October 2021

Publisher's Note: MDPI stays neutral with regard to jurisdictional claims in published maps and institutional affiliations.

Copyright: (c) 2021 by the authors. Licensee MDPI, Basel, Switzerland. This article is an open access article distributed under the terms and conditions of the Creative Commons Attribution (CC BY) license (https:// creativecommons.org/licenses/by/ $4.0 /)$.
Abstract: Hydrocarbons are traditional subjects to European Union (EU) law ("acquis communitaire"). A short historical review reveals that quasi all aspects of upstream and downstream segments are covered by the legislation. The results of applied information extraction and elaborated quantitative analysis indicate that the intensity of legislation making correlates with global drivers such as oil price booms, and technology developments such as extraction of unconventional hydrocarbons by hydraulic fracturing. A quarter of a century after the Hydrocarbons Directive was published and transposed by Member States (MS), data allow us to make a semi-quantitative assessment on the implementation, the major drivers of governments' publication activity, and the impact on the oil and gas production. Another specific relevance of this study is on non-energy minerals management of the EU, whether the introduction of similar competitive bidding rules would induce a greater interest of investors, and the enhanced competition could bring more benefits to the states by the rejuvenation of the critical minerals extractive sector. The preliminary findings show that in some MS there is a positive correlation between the concession call publication activity and hydrocarbons production. To confirm these conclusions the analysis of an extended dataset including exploration data, investments, and social impacts is needed in order to screen the effect of global market trends, the exhaustion of domestic geological reserves, and the different policy environments.

Keywords: hydrocarbons; oil and gas; upstream and downstream; exploration and production; concession tender; legal governance; European Union; critical minerals

\section{Introduction}

Oil and gas are fossil fuels, non-renewable resources that account for $60-65 \%$ of the total final energy consumption and $20-25 \%$ of the domestic energy production in the EU (IAE, [1]). MS have sovereignty over fossil fuels and minerals on their territories because most segments of this sector, especially the proprietary decisions on the extraction, are out of the scope of the EU primary legislation, i.e., the Treaty of the Functioning of the EU (TFEU) (Hámor [2], Hámor et al. [3] Hámor-Vidó et al. [4]). In 1994, a progressive piece of EU secondary legislation was published on the rules of hydrocarbons exploration and production (Directive 94/22/EC of the European Parliament and of the Council of 30 May 1994 on the conditions for granting and using authorizations for the prospection, exploration and production of hydrocarbons) (hereinafter: "Hydrocarbons Directive" or "Directive") in order to ensure open and fair competition. The European Commission (EC) monitors the implementation of EU legislation; however, no such report has been published since 1998 (EC [5]), in spite of the obligation of Article 9 that MS shall publish an annual report on the geographical areas opened, authorizations and entities granted, as well as the reserves.

Hydrocarbons' importance is still significant in the EU. Domestic reserves are limited but due to the decarbonization efforts, its criticality is diminishing (Hamor-Vido et al. [4]). 
On the contrary, the number of critical minerals more than doubled in nine years (from 14 to 30 ).

Three policy contexts highlight the importance of this study:

(a) the growing interest in exploring domestic unconventional hydrocarbons in Europe induced by the US shale gas boom;

(b) the EU non-energy raw materials policy targeting efficient governance tools; and

(c) the Energy Union Regulation which is to integrate, amend, replace and withdraw certain obligations contained in sectoral energy and climate legislative acts, including the Hydrocarbons Directive, to ensure a streamlined and integrated approach to the main planning, reporting and monitoring strands.

The technology development at hydraulic fracturing and the revision of the conventional exploration and extraction methods of hydrocarbons brought a major breakthrough in the US energy mix at the turn of the century, known as the "shale gas boom". This success story has not been repeated in Europe yet. The rally for unconventionals reached Europe with a certain delay in 2005-2010 (Tzimas et al. [6]), and almost immediately it generated public opposition (Urbaniak et al. [7]) and political attention. In 2011, France introduced an absolute ban on hydraulic fracturing. Some MS followed this (e.g., Bulgaria); others were supportive (UK, Poland, Ireland), or took a neutral stand-by position (e.g., Germany, Hungary). In 2012, the European Parliament (EP) issued a resolution with numerous recommendations (EP [8]), and later the European Economic and Social Committee acted (EESC [9]). As a follow-up, the EC launched a set of studies (EC [10-13]; AEA [14]; KPMG [15]; AEA [16]; UBA [17]; Milieu [18]; Amec [19]; Mitchell et al. [20]; Durling et al. [21]) and a public consultation. As an outcome, the EC published a Communication (EC [22]) and a recommendation on the minimum principles for the exploration and production of hydrocarbons (such as shale gas) using high-volume hydraulic fracturing (EC [23]). Its application was reviewed two years later (EC [24]).

The EU Raw Materials Initiative's (EC [25]) scope is on non-energy, non-food primary and secondary raw materials. Its second pillar is to reinforce the sustainable supply from domestic European sources. The European Innovation Partnership (EIP) on Raw Materials (EC [26]) translated the strategic policy framework into actions and mobilized the stakeholder community. The EIP's Strategic Implementation Plan (EIP SIP) (https: / / ec.europa. eu/growth/sectors / raw-materials / eip/strategic-implementation-plan_en (accessed on 4th October 2021)) in 2013 offered an agenda on research and innovation actions, inter alia, it is calling for setting right framework conditions via streamlined permitting procedures.

In 2014, the Ad Hoc Working Group on "Exchange of best practices in minerals policy and legal framework, information framework, land-use planning and permitting" (Christmann et al. [27]) proposed a provisional list of topics to be regulated at EU level (e.g., through a Commission Decision), such as good governance, stable and predictable legal and regulatory framework, transparency, undistorted market conditions, defining "mineral deposits of public importance", etc. It also proposed mandatory publication of calls with regard to areas open for exploration and extraction of critical minerals, similar to what the Directive introduced. EC [28] published a review of minerals permitting and concluded that there were significant differences among the MS in legislation, permitting practices, involved authorities, procedural details, and fiscal conditions.

This study is a review on the implementation of the Directive based on a quantitative assessment of 25 years of publication practices of MS on hydrocarbon exploration and production tenders. The analysis of the national governance covers aspects such as the typology of the calls, the competent authorities, the relevant legislation, and the number and volume of published calls. It also includes the comparison with global market price trends, the effect of technology and policy drivers, as well as the historical trends of EU lawmaking. The study draws conclusions on the impacts of open competition with the ambition that the results could be used in both the energy and non-energy extractive sector. The study does not aim at an analysis of the EU energy policy or recent 
studies on renewable fuel technologies. These aspects are published in numerous works (e.g., Matláry [29]; Li et al. [30,31]).

\section{Methodology}

For the study of the legislation, the authentic EUR-Lex database was queried, and analyzed using text mining techniques, and relevant works (e.g., EC [28]; Hámor [2]; Hámor et al. [3]) were reviewed. EU Community law is often cited as "supranational" law. Primary legislation involves treaties and international conventions. Treaties define the thematic scope of the acquis, the responsibilities of EU institutions and the legislative, executive and juridical procedures. Secondary law is: (a) regulations, directly applicable and binding in all MS; (b) directives, binding as to the objectives to be achieved, while leaving MS the choice of form and tools to be used; and (c) decisions, binding for those to whom they are addressed (https:/ / ec.europa.eu/info/law/law-making-process/ types-eu-law_en (accessed on 4th October 2021)).

MS legislation shows a similar hierarchy. Acts or laws are issued by the National Assemblies (Parliaments), regulations, decrees and orders by the Governments and the Ministers. Regional and local governments also have the right to publish decrees in their sphere of competence. Government agencies may publish orders and guidelines as well, but these less commonly have legal effect.

Union competences are steered by the principles of subsidiarity and proportionality. In areas which do not fall within its exclusive competence, the Union acts only if and in so far as the goals of the proposed action cannot be sufficiently achieved by MS, either at central, regional, and local scale, but can rather, by reason of the level or effects of the proposed action, be better achieved at Union level (TFEU) Art. 5. Under the principle of conferral, the EU acts within the limits of the competences conferred upon it in the TFEU (https:/ / ec.europa.eu/info/law/law-making-process/types-eu-law_en (accessed on 4 October 2021)).

For a quantitative trend analysis, the advanced search functions of the EUR-LEX were used with the "all documents" setting and with the "legal acts" setting, respectively, for all searched words. The former includes all EU documents, the latter covers pieces of law exclusively. The text search function was applied for words "energy", "hydrocarbon" and "oil" AND "gas". The examined period is 1970-2020. This methodology was introduced and tested by Hámor et al. [3] on the EU scale.

According to Article 3 of the Directive, MS publish their concession calls for hydrocarbons in the Official Journal of the European Community. The advanced search engine of EUR-LEX allows downloading of all related documents.

The data on production were extracted from the EUROSTAT database. The oil price curve is based on the average annual OPEC crude oil price (https://www.statista.com/ statistics/262858/change-in-opec-crude-oil-prices-since-1960/ (accessed on 4 October 2021)).

The authors' efforts failed to find public data on the direct investment in the hydrocarbon industry, or any indicators of exploration activities (number of wells, drilled meters, number or length of seismic lines, number of companies, number and size of concession areas, evolution of reserves volumes) which could reflect the trend of upstream activities during the last 25 years in Europe.

\section{Results}

\subsection{Hydrocarbons in the Acquis}

In the TFEU, "energy" and "environment" are sectors of "shared competence", meaning that the EU may act but MS cannot so long as the EU is acting ("pre-emption"). The Amsterdam Treaty (1997) implemented a coherent community policy on the environment by adopting the concept of sustainable development: "this policy shall contribute to a pursuit of the objective of prudent and rational utilization of natural resources." The earliest pieces on the environment were on dangerous chemical substances (Appendix A [1]), waste management (Appendix A [4]), and water (Appendix A [6]). In the 20th century 
the minerals extractive industry was excluded from the scope of environmental directives Hamor [2]; Hamor et al. [3]). The upstream of the hydrocarbons sector, i.e., exploration and extraction, was out of scope (e.g., Waste Framework Directive, Appendix A [4]) but the downstream such as distillation, refining, processing, storage were covered by the Seveso I Directive (Appendix A [7]), and others on minimum stocks of crude oil (Appendix A [2]), on workers safety and health issues (Appendix A [9]), trade, procurement. Since 1972 MS had to report their hydrocarbon production, transport, storage or distribution projects above a certain threshold (Appendix A [3]). In 1990, the whole sector came to the scope of the procurement rules (Appendix A [10]).

At the turn of the century, mainly due to tailings dam failures, the sector was brought to the scope of the environmental legislation, including the Extractive Waste Directive, the Water Framework Directive, the Environmental Impact Assessment Directive, the Industry Emissions Directive, the REACH Regulation on chemicals, the Seveso Directive on industry accidents, to mention a few (Appendix A [24,45,46,70-72]). The Energy Community Treaty was published in 2006 (Decision 2006/500). It provides for the creation of an integrated market in natural gas and electricity in South-East Europe with a stable regulatory and market framework capable of attracting investment in gas networks, power generation and transmission networks, so that Parties have access to the stable supply. It enables the efficient operation of energy markets, including congestion management, cross-border flows, and power exchanges. Later the energy policy developed to a higher level of integration by ensuring supply security via transnational network grids, the promotion of renewable energy and energy efficiency, and the de-carbonization of the energy mix in harmony with global climate agreements.

A complete list of EU legislation on the hydrocarbons sector is provided in the Annex. During the last 20 years, the scope of the environmental acquis covered most environmental compartments, with the exception of soil and subsoil, and major emitting sectors and waste streams (Hámor [2]; Hámor-Vidó et al. [4]).

The US shale gas revolution had not generated prompt precautionary measures at the EU policy making, in spite of the fact that numerous oil and gas companies launched exploratory projects in Poland, Hungary, and the UK. It came into political focus in 2011 when France introduced an absolute ban on hydraulic fracturing.

2012 was earmarked with more studies, bans (e.g., Bulgaria), or supportive positions (UK, Poland, Ireland) and neutral stand-by (e.g., Germany). The EP Resolution was a milestone with 114 statements and recommendations:

- $\quad$ The acquis adequately covers this industry;

- $\quad$ Robust national regulatory regime is needed;

- Environment-friendly processes, etc. should be used;

- Importance of transparency and fully consulting the public;

- $\quad$ MS should adopt a one-stop-shop approach to permitting and examination of compliance with environmental regulations (incl. mandatory impact assessment);

- Mandatory approval of the local authorities affected;

- Special plans for water use should accompany any hydraulic fracturing.

As a follow-up, the EC launched a public consultation and published the Recommendation on the minimum principles for the exploration and production of hydrocarbons (such as shale gas) using high-volume hydraulic fracturing (EC [23]). Although the Recommendation is not mandatory, it is expected that those MS which adopt it voluntarily should be in compliance with its regulatory solutions and report on the implementation.

In 2015, a Science and Technology Network was launched, and a Technical Expert Group was established for preparing a best available technique reference document ("BREF") on hydrocarbons exploration and extraction (http:/ / ec.europa.eu/environment/ integration/energy/hc_bref_en.htm (accessed on 4th October 2021)). An IMPEL (EU Association of Environmental Law) project provided an analysis of the acquis and of the participating MS legislation (UK, HU, PL, NL, FR, RO) (Mitchell et al. [20]; Durling et al. [21]). The EC proposed the European Chemicals Agency (ECHA) to make changes 
in the database of registered chemicals to facilitate information on substances used in hydraulic fracturing.

The above studies conclude that there is no one piece of EU legislation which is specific to unconventional hydrocarbons or hydraulic fracturing. Beyond this general lack, there are uncertainties in interpreting existing pieces. The Strategic Environmental Assessment Directive (Appendix A [28]) requires an assessment of plans and programs, particularly in the areas of energy, industry, waste management, water, transport and land use. Hydrocarbon projects (drilling, production, water discharge, etc.) are listed in its Annex. Recommendation 2014/70/EU invites MS to carry out an assessment before granting licenses that may require the use of high-volume hydraulic fracturing. Reasonable alternatives to the proposed project must also be considered. The Chemicals Regulation (Appendix A [45]) could be more specific with regard to registration and reporting the composition of fracking fluids and drilling muds, and in providing volume thresholds.

The Seveso Directive (Appendix A [72] on industry catastrophes is applied for the sector, including waste management, i.e., drilling mud and fracking fluid disposal in ponds above a certain volume of dangerous substances. It requires operators to have policies preventing major accidents and, in the case of "upper-tier establishments", to produce a safety report and internal emergency plans.

The Extractive Waste Directive and its daughter decisions (Appendix A [46,62-66,98]), as well as the Waste Framework Directive and the European Waste Catalogue (Appendix A [26,55]) are applicable for drilling muds and cuts (rock chips), but the coverage of used fracking fluids (incl. proppants) is questioned. If extractive waste transported off-site (e.g., hazardous drilling mud) it may be disposed of at commercial landfills, although it is not a practice in MS. The interpretation of the acquis on naturally occurring radioactive materials (NORM) is unclear.

Oil and gas activities may also be subject to EU nature conservation based on two Directives (Appendix A [14,61]). If a foreseen project may affect a Natura 2000 site in a significant manner, a prior appropriate assessment must be carried out (Hámor et al. [32]). However, the implementation of these provisions could be uneven across MS.

The water legislation (Appendix A $[24,48]$ ) focus is mainly on water quality, quantitative issues are less regulated. Article 11 (3.j) is the basis of debates for interpretation: "Member States may also authorise, specifying the conditions for injection of water containing substances resulting from the operations for exploration and extraction of hydrocarbons or mining activities, and injection of water for technical reasons, into geological formations from which hydrocarbons or other substances have been extracted or into geological formations which for natural reasons are permanently unsuitable for other purposes. Such injections shall not contain substances other than those resulting from the above operations". Permit conditions may not require monitoring or measures to prevent hydraulic fracturing leading to impacts on aquifers.

In the Industry Emissions Directive (Appendix A [70]) a potential gap arises because of uncertainty over the hazardous character of fracturing fluids which would determine its applicability to hydraulic fracturing installations. The monitoring requirements may not be applied. There is no explicit mentioning of the sector, therefore no complex environmental permit under the Directive is required.

The air and noise legislation has no explicit rules on these activities (Appendix A $[19,23,29,32,36,41,43,53])$. Competent authorities are responsible for permitting emissions to air, especially during drilling, fracturing and traffic, therefore no specific measures for emission abatement may be required. Fracking induced seismicity is out of the scope of the acquis. Fracking induced earthquakes at unconventional hydrocarbon fields and at deep geothermal projects are well documented (https: / / www.insidescience.org/news / 2019-year-fracking-earthquakes-turned-deadly (accessed on 4th October 2021)) (GoertzAllmann et al. [33]; Soltani et al. [34]).

What concerns the downstream of the sector, the Natural Gas Directive (Appendix A [58]) is on supply security, consumers protection, access to transmission systems, and so on. 
Pipeline networks are subject to the Directive but with no details on the underground setting. The transport and distribution network are covered by the Regulation on transEuropean energy infrastructure and Regulation on measures to safeguard the security of gas supply (Appendix A [73,91]). The Deepwater Horizon disaster in 2010 induced a set of precautionary measures in the EU by regulating the offshore segment and parallel to it the marine policy developed (Appendix A $[74,77,80,84,90])$.

\subsection{Regulatory Instruments of the Hydrocarbons Directive}

The Directive was adopted on 30 May 1994 and came into effect on 30 June 1994. The deadline of transposition was 1 July 1995. National harmonizations were fluent, no pilot or infringement cases are known. Luxembourg and Finland are exempt from transposition by having no hydrocarbon resources. Article 13 provides a temporary derogation for Denmark that Articles 3 and 5 do not apply to new authorizations granted before 31 December 2012, in respect of the areas which are relinquished on 8 July 2012 upon expiry of the authorization issued on 8 July 1962. The Directive is also in force in the European Economic Area, Iceland and Norway publish calls regularly.

In the Directory of EU legal acts the Directive is classified to subchapters "06.20.10.20 Right of establishment and freedom to provide services/Sectoral application/Production and processing activities/Other production and processing activities", and to "12.50.30.00 Energy/Oil and gas/Other measures relating to oil or gas".

Since its publication, the Directive had one major amendment by Regulation 2018/1999/EU on the Governance of the Energy Union and Climate Action. It annulled Article 9 on the reporting obligation, and paragraph 2. of Article 8 on the reporting obligation of the EC on European oil and gas companies' activities in third countries. The 2016 Fitness Check proposed to repeal these by referring that their implementation failed (EC [35]).

To reinforcing the integration of the EU internal energy market, encouraging fair competition and improving the safety of supply, new rules are established by the Directive which guarantees non-discriminatory access to the prospection, exploration and production of oil and gas. It also provides the option to impose conditions and requirements on the ground of public health and protection of the environment. MS have sovereign rights over these resources within their territories. It is therefore up to MS decision makers to determine the geographical areas where the rights to explore and extract hydrocarbons can be exercised and to authorize companies to exercise those rights. Moreover, on the grounds of national security, states may refuse the claim of any entity.

The Directive stipulates that the borders of the geographical territories covered by a permit and the duration has to be defined in proportion to what is justified by means of the best possible performance of the activities from an economic and technical perspective. The objective is to prevent a single entity from bearing exclusive rights for an acreage whose activities can be performed more efficiently by multiple companies. The paragraph which provisioned for a single entity the right to acquire authorization was repealed by January 1997 (Art. 7).

According to Article 3, granting authorizations can be through

a "licensing round" system initiated either by

(aa) the competent authorities, or

(ab) by an entity; or

an "open door" system where the publication is not necessary in case

(ba) the area is available permanently, or

(bb) was already published but without granting, or

(bc) the area was given back by the entity; or

(bd) the area is contiguous to an active concessional area.

The two systems can be combined.

All information must be published in the Official Journal of the European Union at least 90 days before the deadline for the submission of applications. The procedures for granting authorizations must be introduced in a transparent manner based on objective, 
non-discriminatory criteria, open to all interested entities. The selection among the various entities is based on their technical and financial capabilities, record of performance, proposed exploration and/or production, and the price which the entity is prepared to pay in order to obtain the authorization. MS may limit the publication of the criteria in case they already published those in their national journal (Art. 5(1)). MS may retain the right subject to considerations of national security, public health and safety, security of transport, protection of the environment and biological resources, the planned management of hydrocarbon resources. Most MS do not specify in their publications whether the call applies for unconventionals and fracking.

In line with the reciprocity principle with third countries, MS' entities must be able to receive treatment in third countries which is comparable to that which third countries' entities receive in the EU (Art. 8). MS are required to provide the list of their competent authorities, and any subsequent changes (Art. 10).

The implementation and interpretation of the Directive generated only a few EU Court of Justice cases. The Directive complements the Directive 2014/25/EU on the procurement procedures of entities operating in the water, energy, transport and postal services sectors (originally Directive 90/531).

\subsection{National Regulatory Solutions}

T he EUR-LEX database contains 718 documents in context of the Directive as of 31 December 2020. In all, 633 documents were published by 23 EU countries, 33 documents by EEA countries (Norway and Iceland), and 52 documents by the EU Court of Justice, EC, EP, EEA, EFTA. Estonia, Finland, Luxembourg, Slovenia, Sweden and Flanders (Belgium) did not publish any calls. The case of Estonia is somewhat surprising since it has the biggest oil shale production in Europe. According to the EUROSTAT, also Slovenia has hydrocarbon production, though insignificant.

The title of the publications is diverse: it can be a notice, communication, notification, announcement, invitation, application and corrigendum (Table 1).

Table 1. Basic information on countries publishing calls in context of the Hydrocarbons Directive.

\begin{tabular}{|c|c|c|c|c|c|c|}
\hline Country & $\begin{array}{c}\text { Year of } \\
\text { Accession }\end{array}$ & $\begin{array}{c}\text { Publishing Period } \\
\text { (Year) }\end{array}$ & $\begin{array}{l}\text { Number } \\
\text { of Docs }\end{array}$ & $\begin{array}{l}\text { Number } \\
\text { of Pages }\end{array}$ & $\begin{array}{l}\text { Mean } \\
\text { Value }\end{array}$ & Call Type \\
\hline Austria (AT) & 1995 & 1995-2020 & 3 & 4 & 1.3 & open door \\
\hline Belgium (BE) & 1952 & $2007-2020$ & 5 & 9 & 1.8 & licensing rounds, entity initiative \\
\hline Bulgaria (BG) & 2007 & 2015-2020 & 2 & 5 & 2.5 & licensing rounds \\
\hline Croatia (HR) & 2013 & $2014-2020$ & 6 & 14 & 2.3 & licensing rounds \\
\hline Cyprus (CY) & 2004 & 2007-2016 & 6 & 12 & 2.0 & licensing rounds \\
\hline Czech Republic (CZ) & 2004 & 2006-2014 & 5 & 8 & 1.6 & licensing rounds, entity initiative \\
\hline Denmark (DK) & 1973 & 1997-2018 & 6 & 8 & 1.3 & licensing rounds \\
\hline France (FR) & 1952 & 1994-2017 & 159 & 283 & 1.8 & licensing rounds, entity initiative \\
\hline Germany (DE) & 1952 & 1994 & 1 & 1 & 1.0 & open door \\
\hline Greece (EL) & 1981 & 1996-2017 & 8 & 26 & 3.3 & licensing rounds, entity initiative \\
\hline Hungary (HU) & 2004 & 2005-2019 & 71 & 294 & 4.1 & licensing rounds \\
\hline Ireland (IE) & 1973 & 1994-2015 & 9 & 19 & 2.1 & licensing rounds \\
\hline Italy (IT) & 1952 & 1998-2016 & 53 & 96 & 1.8 & licensing rounds, entity initiative \\
\hline Latvia (LV) & 2004 & 2008-2009 & 3 & 4 & 1.3 & open door \\
\hline Lithuania (LT) & 2004 & 2012-2018 & 2 & 4 & 2.0 & licensing rounds \\
\hline Malta (MT) & 2004 & 2005-2019 & 8 & 9 & 1.1 & open door \\
\hline Netherlands (NL) & 1952 & 1995-2020 & 155 & 186 & 1.2 & licensing rounds \\
\hline
\end{tabular}


Table 1. Cont.

\begin{tabular}{ccccccc}
\hline Country & $\begin{array}{c}\text { Year of } \\
\text { Accession }\end{array}$ & $\begin{array}{c}\text { Publishing Period } \\
\text { (Year) }\end{array}$ & $\begin{array}{c}\text { Number } \\
\text { of Docs }\end{array}$ & $\begin{array}{c}\text { Number } \\
\text { of Pages }\end{array}$ & $\begin{array}{c}\text { Mean } \\
\text { Value }\end{array}$ & Call Type \\
\hline Poland (PL) & 2004 & $2006-2020$ & 79 & 541 & 6.8 & licensing rounds \\
\hline Portugal (PT) & 1986 & 1994 & 1 & 1 & 1.0 & open door \\
\hline Romania (RO) & 2007 & $2007-2009$ & 4 & 41 & 10.3 & licensing rounds \\
\hline Slovakia (SK) & 2004 & $2006-2019$ & 6 & 11 & 1.8 & licensing rounds, entity initiative \\
\hline Spain (ES) & 1986 & 1995 & 1 & 2 & 2.0 & open door \\
\hline United Kingdom (UK) & 1973 & $1995-2019$ & 40 & 100 & 2.5 & licensing rounds \\
\hline Iceland (IS) & n.a. & $2009-2011$ & 2 & 6 & 3.0 & licensing rounds \\
\hline Norway (NO) & n.a. & $1996-2020$ & 31 & 52 & 1.7 & licensing rounds \\
\hline
\end{tabular}

Seventeen MS publish "licensing round" notices, of which six are based on or combined with company initiatives. Six MS applied the "open-door" system via a singular communication or two, for example Austria, Bulgaria, Germany, Ireland, Latvia, Lithuania, Portugal, Spain. Denmark, France, and the UK originally choose this option but later changed to concession calls for the open areas. In general, countries are rather flexible with the categories of the Directive. In EEA, both Iceland and Norway apply licensing rounds.

Six MS applied the options of the Directive voluntarily for other energy fuels, nonenergy minerals and surveys such as geothermal energy (Italy, Hungary), metalliferous ores, lignite, and coal (Hungary, Püspöki et al. [36]), coalbed methane (Belgium, Poland), and gravimetric survey (Croatia), respectively. This is a proof that countries prefer publishing open calls in the EU Official Journal as these generate a wide attention of potential investors in addition to national level calls, international roadshows and other promotions.

As indicated in Table 2, in the majority of countries (14 MS) the publishing entity is the Government (or State, Council of Ministers), and a Minister in charge of the sector. Among these, the publisher and final decision maker is the Government of Croatia, Cyprus, Germany, Romania, and the UK. In eight countries, besides the Government, a Minister or Ministry is indicated as the competent entity. In eight MS, and Iceland and Norway a Minister or a Ministry is the competent body. The "lowest" level decision maker in the public administration hierarchy is in Portugal, the Directorate-General for Energy and Geology.

Half of the 18 designated ministries belong to the industry and energy domain, the others' portfolio is on environment and natural resources, and others.

With the exception of three countries (Bulgaria, Czechia, Latvia), there is always a professional government agency or competent authority to assist interested applicants with information, decision makers with professional expert knowledge, and managing the evaluation procedure. These are energy agencies, mining agencies, geological surveys. In Germany and Slovakia first-instance regional mining inspectorates are involved. The Czech Republic and Latvia are the only countries with one entity indicated in the calls.

With the exception of Cyprus, Ireland, Malta and Norway all countries refer to their national legislation. Nine countries have specific acts, laws, regulations on hydrocarbons (Belgium (Walloon), Croatia, Greece, Latvia, Lithuania, Romania, Spain, UK, and Iceland), the rest refer to Mining (and Geology) Acts, Underground Resources Acts and implementing procedural by-laws. 
Table 2. The regulatory framework supervising the hydrocarbons exploration and production activities, as extracted from the recently published calls.

\begin{tabular}{|c|c|c|c|}
\hline & Publisher of Call, Decision Making Entity & Competent Directorate, Authority, Support Agency & National Law \\
\hline AT & $\begin{array}{l}\text { Federal Minister for Agriculture, Regions } \\
\text { and Tourism }\end{array}$ & $\begin{array}{l}\text { Section IV Telecommunications, Postal Services } \\
\text { and Mining }\end{array}$ & Mineral Raw Materials Act \\
\hline BE & $\begin{array}{l}\text { Walloon Government; Walloon Minister for the } \\
\text { Environment, Nature, Forestry, the Countryside } \\
\text { and Animal Welfare }\end{array}$ & $\begin{array}{l}\text { Agriculture, Natural Resources and the Environment, } \\
\text { Industrial, Geological and Mining Risks Directorate }\end{array}$ & $\begin{array}{l}\text { Royal Decree No. } 83 / 1939 \text { on the prospection and exploitation of } \\
\text { bituminous rock, oil and fuel gases; Walloon Government Decree of } \\
19 \text { March } 2009 \text { laying down the format and procedure for examining } \\
\text { applications for licences to prospect for and exploit oil and fuel gases }\end{array}$ \\
\hline BG & Council of Ministers, Minister for Energy & & Underground Natural Resources Act \\
\hline HR & Government & Croatian Hydrocarbon Agency & Hydrocarbon Exploration and Exploitation Act \\
\hline $\mathrm{CZ}$ & Ministry of the Environment & & National Council Act No 62/1988 on geological works \\
\hline DK & $\begin{array}{l}\text { Government; Danish Ministry of Energy, Utilities } \\
\text { and Climate }\end{array}$ & Danish Energy Agency & $\begin{array}{l}\text { Act on the exploitation of underground resources } \\
\text { (Consolidation Act No } 960 \text { of 2011) }\end{array}$ \\
\hline FR & $\begin{array}{l}\text { Government; Ministry for Ecological and } \\
\text { Inclusive Transition }\end{array}$ & Office of Subsoil Energy Resources & $\begin{array}{l}\text { Decree No 2006-648 of } 2006 \text { concerning mining rights and underground } \\
\text { storage rights; Decree No } 2006-649 \text { of } 2 \text { June } 2006 \text { on mining and } \\
\text { underground storage operations and the regulations governing mining and } \\
\text { underground storage }\end{array}$ \\
\hline DE & Federal Government & Mining Inspectorates of the Regions & Federal Mining Law of 13 August 1980 \\
\hline HU & $\begin{array}{l}\text { On behalf of the Hungarian State, the Minister for } \\
\text { Innovation and Technology }\end{array}$ & Hungarian Mining and Geological Service (MBFSZ) & $\begin{array}{l}\text { Act CXCVI of } 2011 \text { on national assets; Act XVI of } 1991 \text { on concessions; } \\
\text { Act XLVIII of } 1993 \text { on mining }\end{array}$ \\
\hline IE & $\begin{array}{l}\text { Minister for Communications, Energy and } \\
\text { Natural Resources }\end{array}$ & $\begin{array}{l}\text { Petroleum Affairs Division of Department of } \\
\text { Communications, Energy and Natural Resources }\end{array}$ & \\
\hline IT & Ministry of Economic Development & $\begin{array}{l}\text { Division VII of the Directorate-General for Security of } \\
\text { Supply and Energy Infrastructure }\end{array}$ & $\begin{array}{l}\text { Law No } 613 \text { of 1967; Law No } 9 \text { of 1991; Legislative Decree No } 625 \text { of 1996; } \\
\text { Ministerial Decree of } 4 \text { March 2011; Director-General's Order of } \\
22 \text { March 2011; Ministerial Decree of } 30 \text { October } 2015\end{array}$ \\
\hline $\mathbf{L V}$ & Ministry of the Economy & & $\begin{array}{l}\text { Cabinet Regulation No } 597 \text { of } 2007 \text { on hydrocarbon prospection, exploration } \\
\text { and production and the amounts of and procedures for paying } \\
\text { Government duties }\end{array}$ \\
\hline
\end{tabular}


Table 2. Cont.

Publisher of Call, Decision Making Entity

\section{Competent Directorate, Authority, Support Agency}

LT Government, Ministry of the Environment

Lithuanian Geological Survey

MT Government, Office of the Prime Minister

NL Minister for Economic Affairs and Climate Policy

PL Government of the Republic of Poland, Ministry

of Climate and the Environment

PT Directorate-General for Energy and Geology

RO Government

SK Ministry of Environment

ES Ministry of Industry and Energy

UK Government

Energy and Environment Directorate

Geology and Geological Concessions Department

Petroleum Exploration Division

National Agency for Mineral Resources

State Geological Administration Department, District Mining Offices

Hydrocarbons Department of the Directorate-Genera for Energy

Oil and Gas Authority

IS Ministry of Industry, Energy and Tourism

National Energy Authority

Norwegian Petroleum Directorate

NO Ministry of Petroleum and Energy

\section{National Law}

Resolution No 299 of 2003 of the Government on regulations governing tender procedures for the exploitation of hydrocarbon resources;

Order No D1-467 of Minister for the Environment of 2004 on the exercise of the functions of the organiser of a tender for the exploitation of hydrocarbon resources

\section{Mining Regulation (Mijnbouwregeling)}

Geological and Mining Law Act

Decree-Law No 139/2007; Order No 27237/2007 (Series 2)

Law No 238/2004 on petroleum; Government Decision No 2075/2004 on Implementing Rules for Law No 238/2004 on petroleum

Act No 44/1988 on the protection and exploitation of mineral resources; Act No 51/1988 of the Slovak National Council on mining activity, explosives and state mining administration

Law 21/1974 on hydrocarbons prospection and production, and its Implementing Regulation Royal Decree 2362/1976

Hydrocarbons Licensing Directive Regulations 1995 (S.I. 1995 No 1434); the Petroleum Licensing (Applications) Regulations 2015 (SI 2015 No 766) Offshore Petroleum Licensing (Offshore Safety Directive) Regulations 2015 (SI 2015 No 385)

Act No 13 of 2001 on Prospection, Exploration and Production of Hydrocarbons (the Hydrocarbons Act) 
Our analyses demonstrate that the most active countries at publishing calls are France, Netherlands, Poland, Hungary, Italy, the UK, and Norway, with 159 to 31 publications (Figure 1). The rest of the countries (18) had less than 10 published calls. The average number of pages of calls reflects the character of legal governance in a given jurisdiction. In this regard (Table 1, Figure 1) Eastern European countries are the frontrunners; Romania (10.3 pages/call) Poland (6.8 pages/call), Hungary (4.1 pages), and Greece (3.8 pages). The commitment of the new MS (2004-2013 accessions) to the Directive's options is evident. With regard to Art. 5(1), very few publications refer to their national calls, not even the 1-2 paged ones, which questions if calls comply with the requirements on the minimum content.

When interpreting the aggregated data, i.e., the number of all published pages (Figure 1), figures confirm the above findings, Poland, Hungary, France, and the Netherlands are the busiest. Surprisingly, with the exception of the Netherlands, these countries are not the biggest oil and gas producers in Europe. Poland, Hungary and France belong only to the third group of countries of hydrocarbons production.

On individual country scale, new exploration concepts and changing governments may have a decisive role in publishing activities, such as the shale gas exploration boom in Poland. In Hungary, the significant increase in publication was due to the re-introduction of the concession scheme in 2010 after a liberal permitting regime.

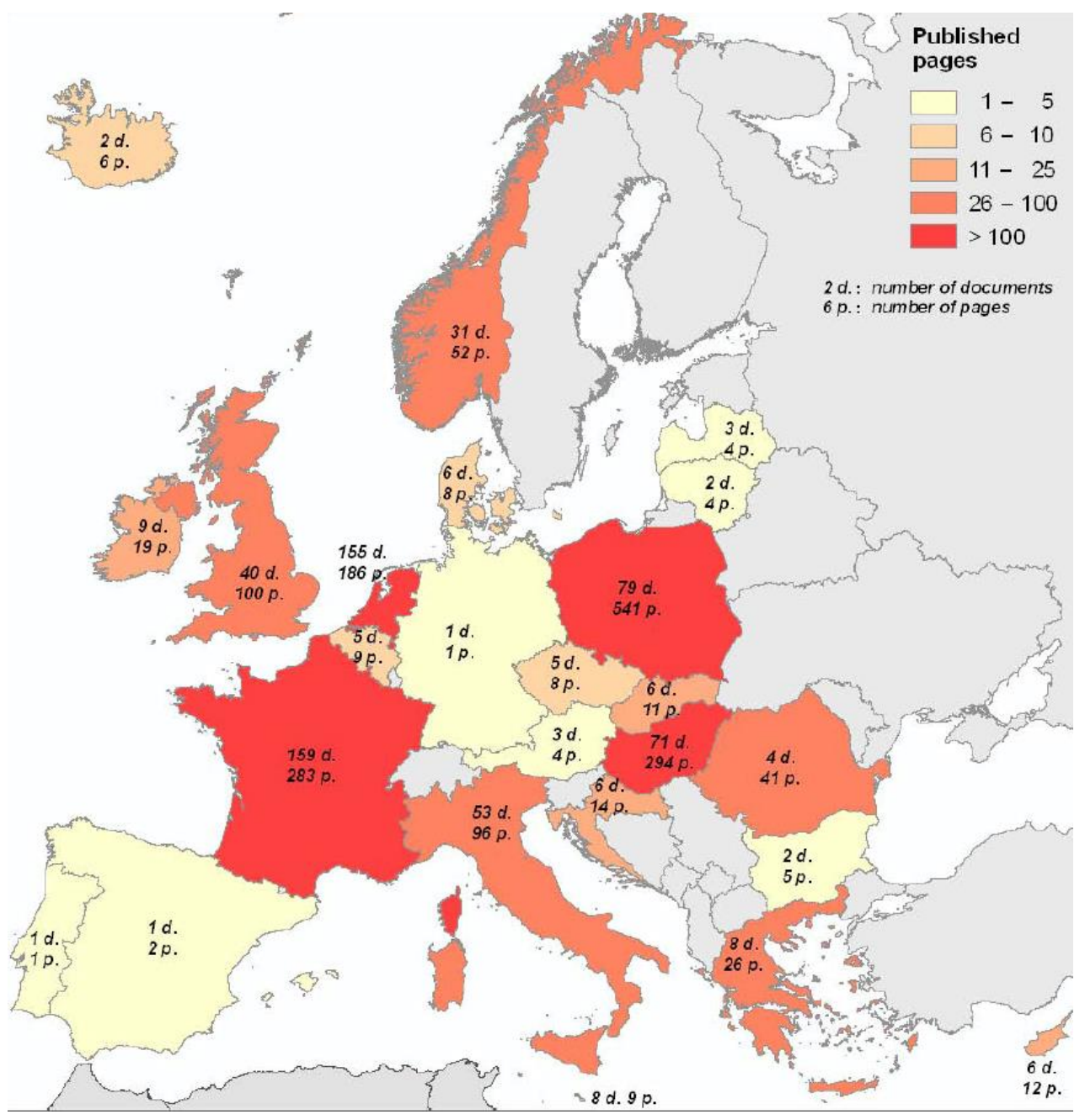

Figure 1. Number and volume of published documents by the contributing countries (1994-2020). Data source: EUR-Lex. Extracted information and map: the authors. 


\section{Discussion}

The EC report on the Directive (EC [5]) concludes that MS have transposed the Directive into national law and confirms that no reciprocity problem was reported. However, most MS do not specify in their published concession tender whether the call applies for unconventionals and fracking. MS may not consider evenly environmental commitments and corporate history of good environmental performance of applicants during the evaluation of tenders.

The reporting obligation for MS in Article 9 is to ensure a non-discriminatory access to and perform activities under conditions which support greater competition favouring best companies. Article 8(2)calls the Commission to report to the Council on the situation of companies in third countries, how reciprocity works.

According to the Fitness Check study (EC [35]), the implementation of Article 9 costs EUR 1,689 /MS/year. The benefits were assessed as significant, but the provision was identified to have quasi no relevance at all, given the fact that the objective of the MS reports is to provide information to the Commission summary under Article 8(2). No such report has been released by the Commission since 1994, partly because the information to be submitted by MS under this obligation "can also easily be acquired via the notified tenders". The study found that "this obligation clearly represents an unnecessary administrative burden for MS". It revealed that such information was not requested by the relevant stakeholders and can therefore be interpreted "not to be seen as providing any potential benefits".

Quite often policy- and law-making are driven by political interests generated by abruptly emerging public pressure, as happened in the case of unconventional hydrocarbons and hydraulic fracturing. The momentum in this case was not sufficient to spur legislation.

The text search scores (Figure 2) for both "energy", "hydrocarbon" and "oil" AND "gas" correlate well with each other, both in "all documents" and in "legal acts". The "energy" legislation peak is in 2014 when the Annex lists 6 pieces of legislation. The peak in 1973 is linked to the first oil price crisis.

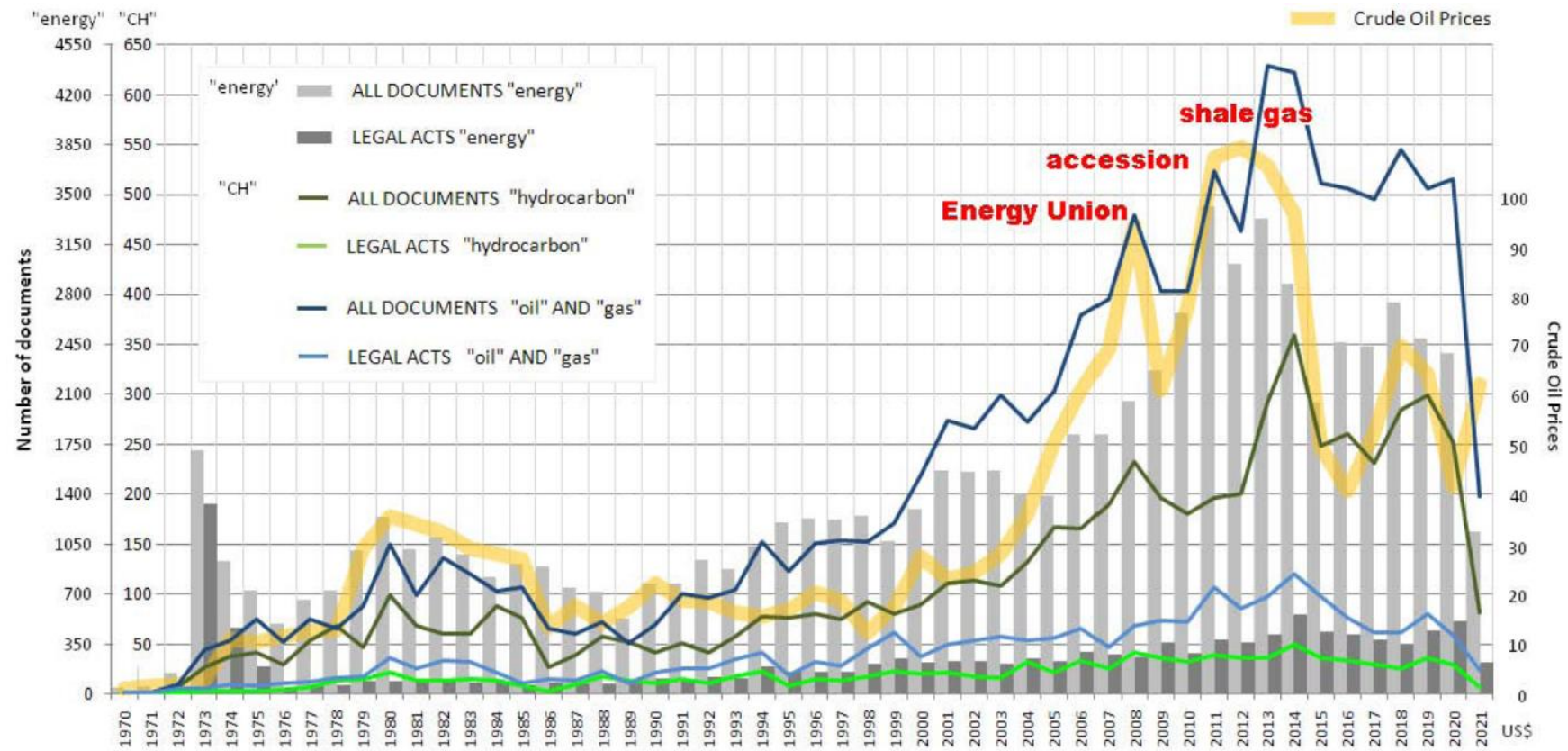

Figure 2. The trend of energy and hydrocarbons related documents and legal texts in the EU versus oil price and other events during the last half century. 
Hydrocarbons is a synonym of oil and gas, but the latter terminology is more in use, almost double in both datasets. There might be specific cases when both the oil and gas occur in the same document but not in the fossil fuel context, e.g., biogas and oilseed.

As expected, 6-10 times more policy documents were published in a given topic than legal texts in the last two decades. The difference was less before the turn of the century. This decoupling may indicate that legislation making was more demanding during the last twenty years.

What concerns the historical trends of the curves, the document peaks show an obvious fit with major events and periods, with a certain delay in response:

the oil price peaks of 1973-74, 1980, 1990, 2011-14;

the preparation for and launch of the Energy Community between 2000-2006;

the economic crisis and induced price boom of 2008;

the accession wave of 12 new MS in 2004 and 2007, and

the political debate over unconventional hydrocarbons and hydraulic fracturing in the period 2011-2014,

however, these latter two periods coincide with the global oil price rise.

Figure 3 presents the annual changes of published documents in the context of the

Directive. There were 1736 pages published in 718 documents until the end of 2020 .

The curves of the number of pages and the number of documents do not necessarily match; the former one has a peak in 2018 related to the detailed calls by Hungary and Poland (see Table 3).

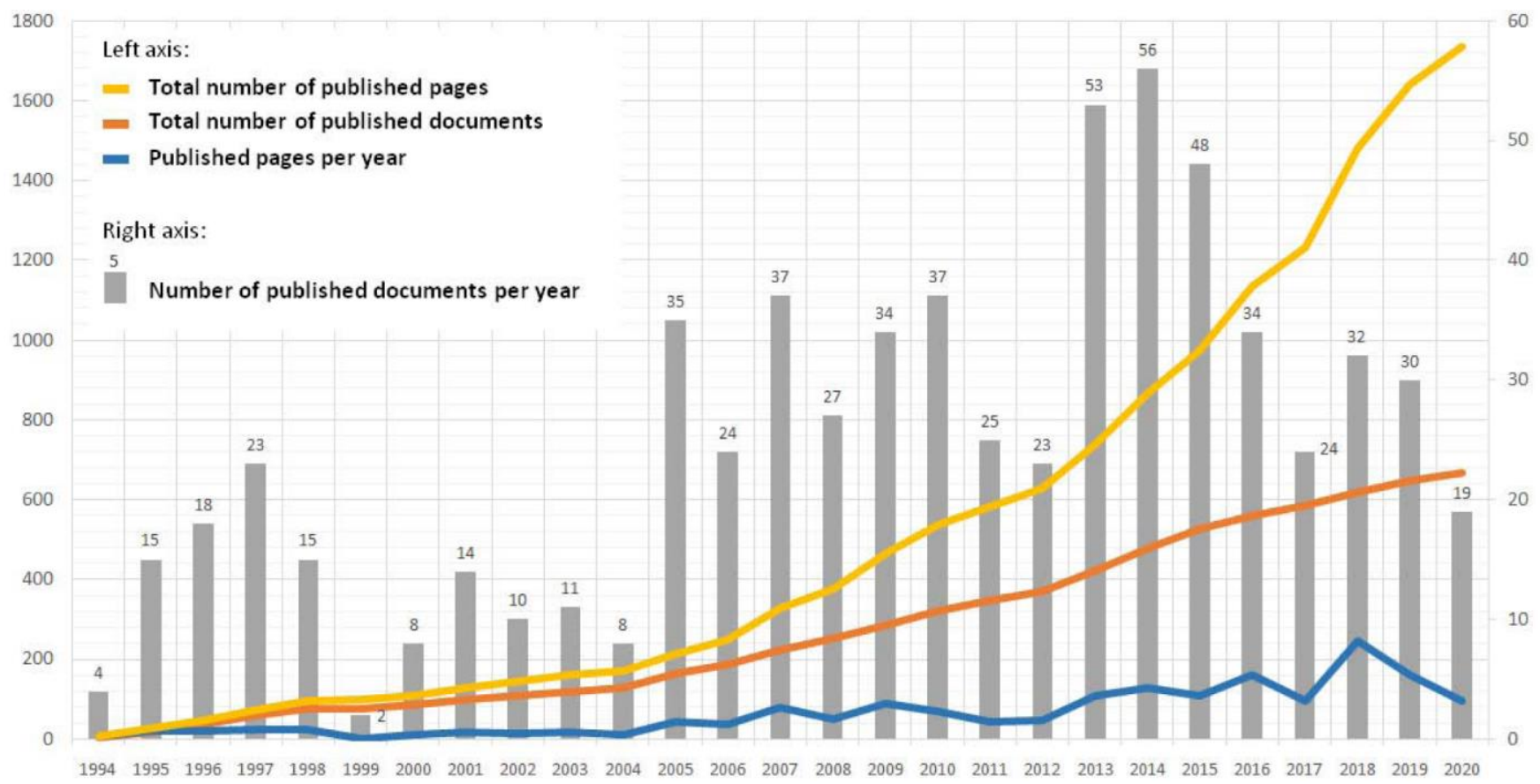

Figure 3. Annual publication activities in the context of the Hydrocarbons Directive.

The first publication peak in 1997 relates to the transposition and the first publications by MS. The second peak in 2001 might be related to the effect of the developing Energy Union. The relatively stable "high-stand" between 2005 and 2010 is likely due to the new accession wave of twelve countries and the 2008 economic crisis. The last and highest peak in the publication activity in 2013-2015 is associated with the unconventional hydrocarbons boom and delayed response to the 2011-2013 price maximum. The historical word search scores in the EUR-LEX and prices (Figure 2), and the number of documents (Figure 3) correlate fairly well and confirm the above findings. 
Table 3. Annual publishing activities and total number of published documents between 1994 and 2020. Data source: EUR-Lex.

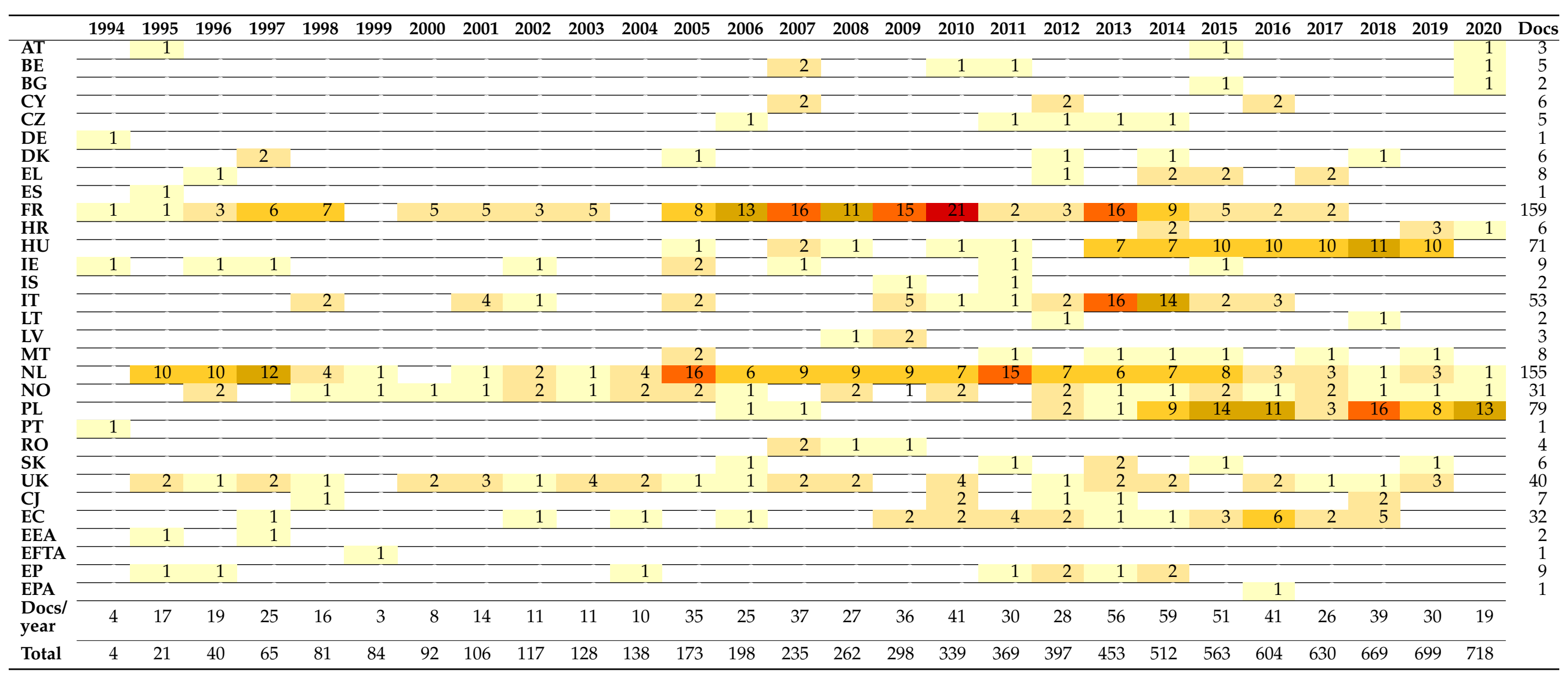


In making an analysis of the legislation, it is beneficial to know what measurable impact it had on the regulated sector. In spite of their efforts, the authors could not find public data on exploration volumes or change in reserves or other figures representative of the upstream (e.g., number of employees, direct investment, royalty paid, etc.). Nevertheless, the annual production data available at Eurostat are visualized in Figure $4 a-d$ where countries are grouped into four clusters.

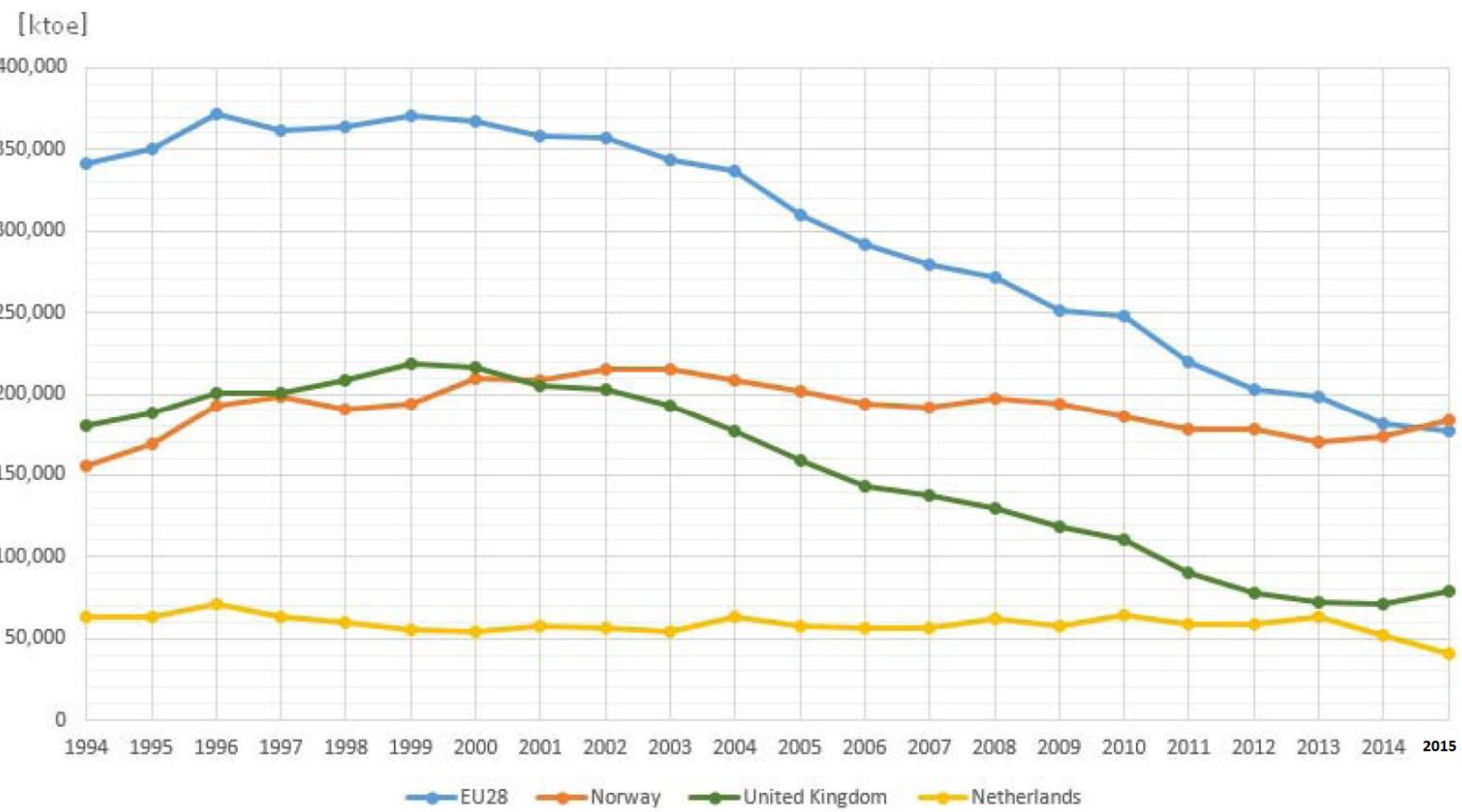

(a)

[ktoe]

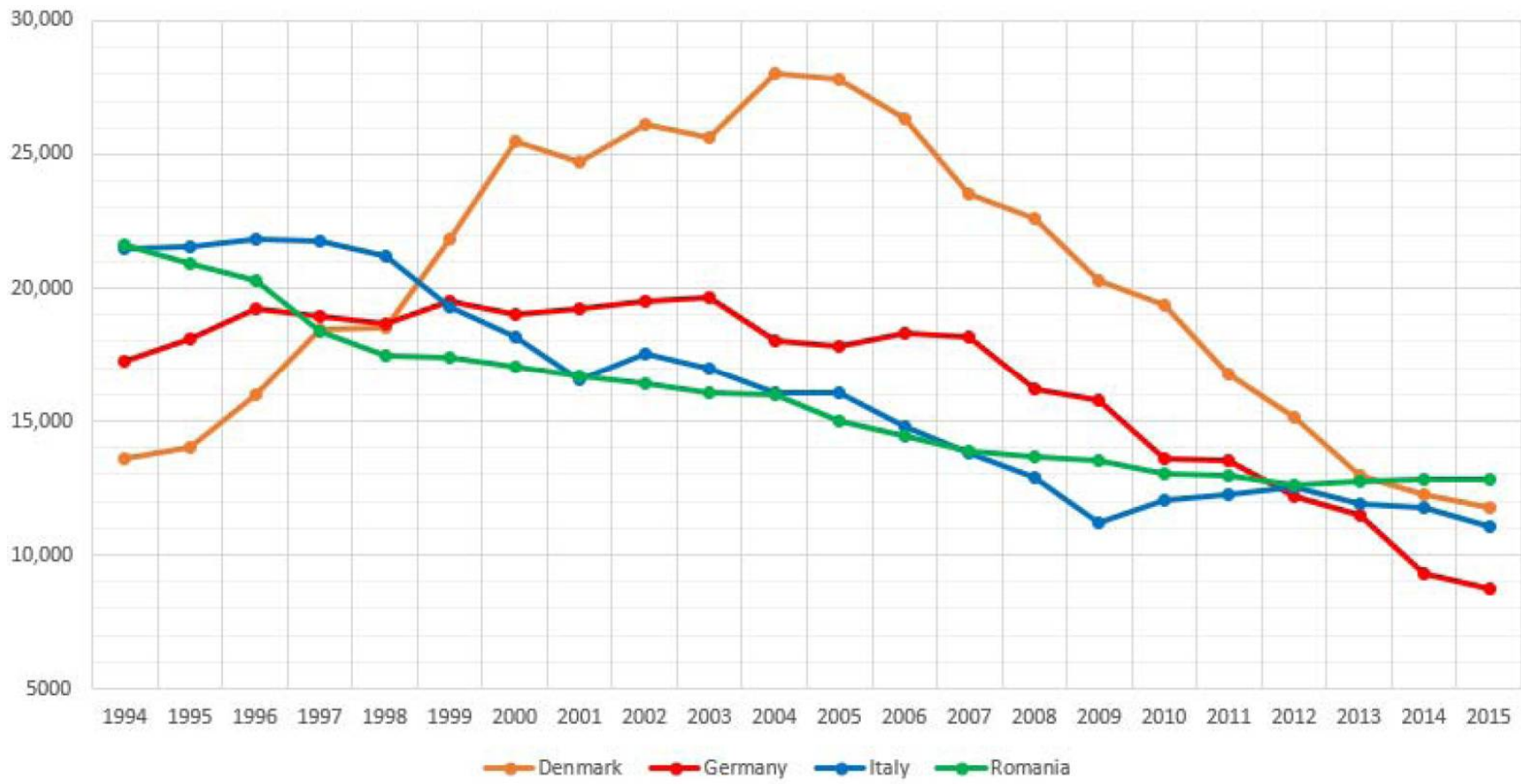

(b)

Figure 4. Cont. 


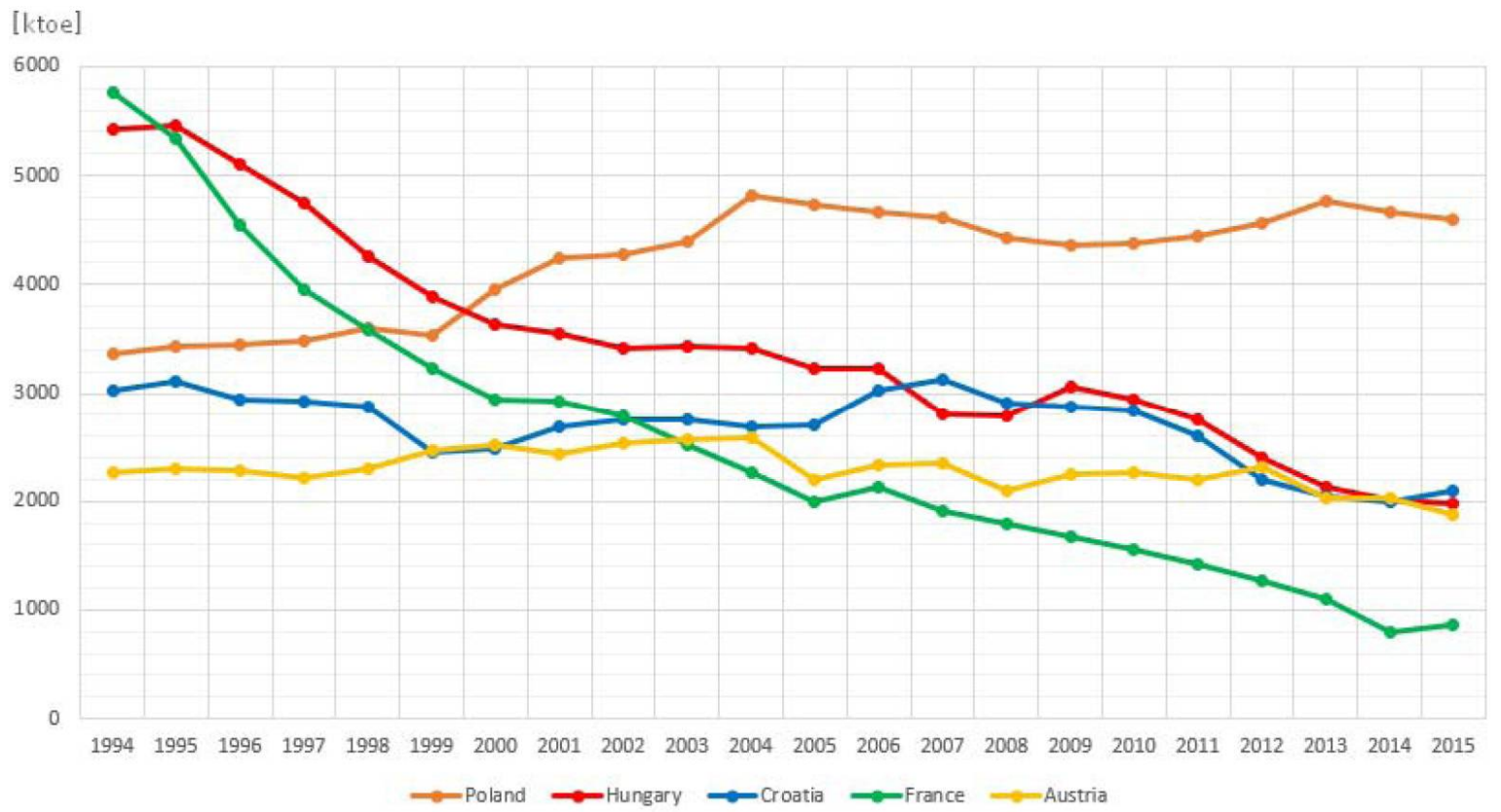

(c)

[ktoe]

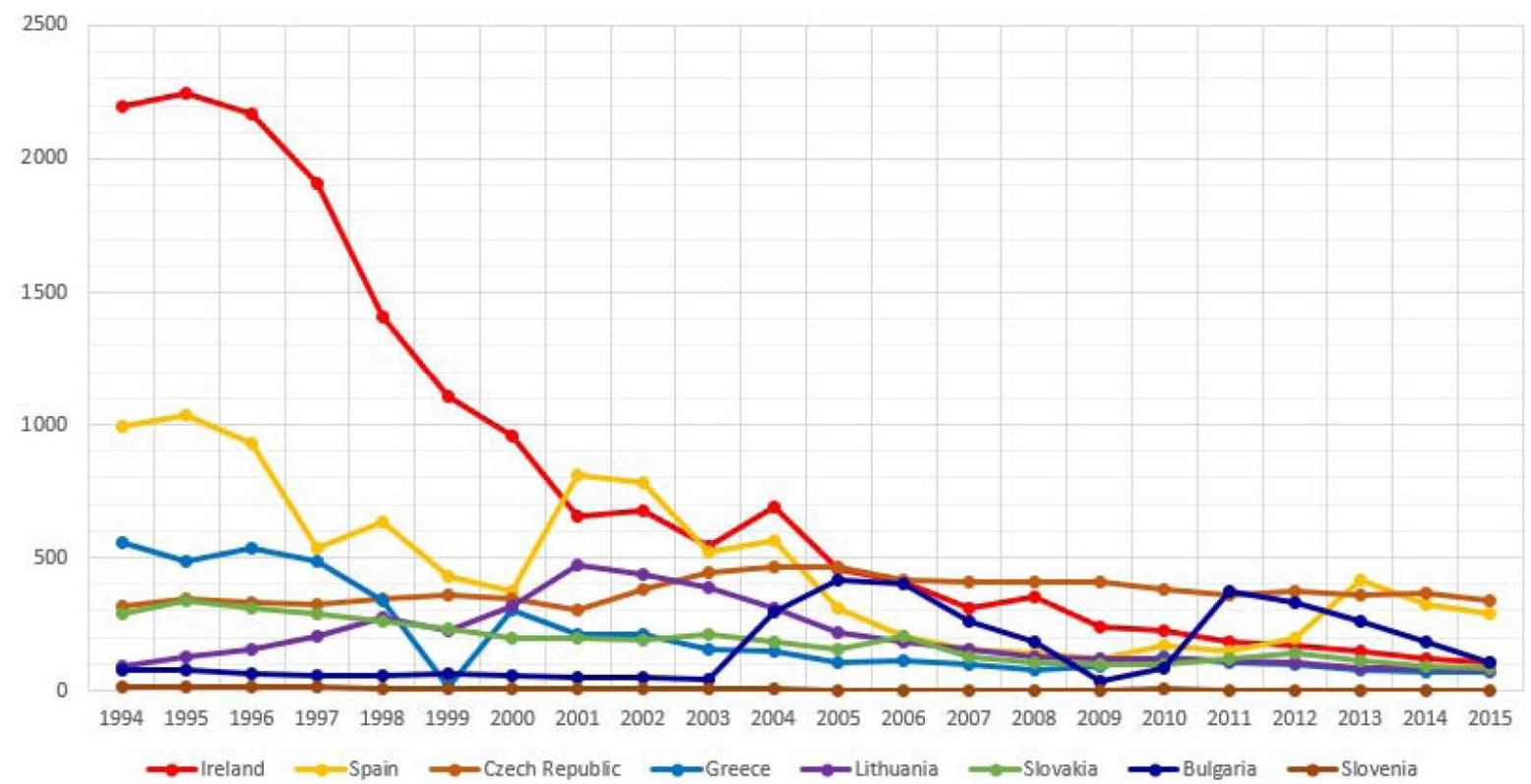

(d)

Figure 4. (a) Primary production (crude oil and natural gas) Class1 ( $\geq 50,000$ ktoe), (b) Primary production (crude oil and natural gas) Class2 (8000-30,000 ktoe), (c) Primary production (crude oil and natural gas) Class3 (1000-6000 ktoe), (d) Primary production (crude oil and natural gas) Class4 ( $\leq 1000 \mathrm{ktoe})$.

Countries with the biggest outputs publish a lot (155 calls by The Netherlands, 40 by the UK, 31 by Norway) but countries in the third (159 calls by France, 79 by Poland, 71 by Hungary) and the second (53 calls by Italy) hydrocarbons output range are similarly or even more active in announcing calls (Table 3 ).

What concerns the trend of production, the continent has a mature extractive sector, outputs are decreasing, and few countries show a stable or slightly increasing production, such as UK, Norway, Ireland, Poland, Hungary, France. When considering that these countries are the most committed in publishing by choosing the licensing rounds option, it is an obvious conclusion that well prepared calls and successful performance of the sector may be interlinked. In countries choosing the licensing rounds option, the state invests in 
knowledge management of the targeted areas in order to make these areas attractive for the potential bidders and investors.

Data source: Eurostat, Complete energy balances [nrg_bal_c], Crude oil, Natural gas.

\section{Conclusions and Policy Implications}

The presented work is one of the first studies which analyze EU policy documents and legislation by quantitative tools involving text mining techniques. This "a posteriori" impact assessment on the EU Hydrocarbons Directive shows that the transposition into national laws was fluent but the implementation was not evenly accurate accrossthe MS. Partly for this reason, reporting and monitoring obligations were repealed in 2018.

The timewise text score curves of the acquis and the publication of hydrocarbon calls correlate with major economic events such as oil price booms, economic crisis, shale gas debate, EU accession waves. On a country scale, new exploration concepts, change in government and amended permitting schemes may also have a role in the publishing activity, for example in Poland and Hungary.

The EU policy and legislation making responded rather promptly to global and European challenges affecting the oil and gas industry, and the energy sector, as indicated by the historical curves of text scores in policy documents and laws. The Hydrocarbons Directive is an adequate piece to steer EU and EEA countries in publishing international calls open to all entities interested in hydrocarbons exploration and production and complying with sustainability criteria. Those countries which periodically re-assess their territories for hydrocarbons potential and serve this information during the licensing rounds are more successful than others who take the "wait and see" position by choosing the "open door" option of the Directive. These results support the conclusion that the introduction of a similar regulatory instrument for non-energy critical minerals could promote the transparent and sustainable exploration and extraction of these natural resources in Europe.

Author Contributions: Conceptualization, methodology, investigation, analysis, writing-original draft preparation and review: Tamás Hámor; data curation, software, formal analysis, visualization, technical editing: Katalin Bódis; funding acquisition, resources, project administration, supervision, validation: Mária Hámor-Vidó. All authors have read and agreed to the published version of the manuscript.

Funding: This research was partly funded by University of Pécs Fund EFOP-3.6.1.-16-2016-00004. The APC was funded by the European Commission Joint Research Centre.

Institutional Review Board Statement: The JRC Pubsy Team accepted the manuscript of this article for publication under No. JRC125765.

Informed Consent Statement: Not applicable.

Data Availability Statement: Public data used in this study are available at the EUR-Lex and the EUROSTAT databases of the EU. Other data sources are referred to in the text.

Acknowledgments: The authors express their gratitude to the peer-reviewers who assured the professional quality. Mária Hámor-Vidó is grateful for Fund EFOP-3.6.1.-16-2016-00004 at University of Pécs for its support. Tamás Hámor is thankful for JRC to cover the APC of this publication.

Conflicts of Interest: The authors declare no conflict of interest.

Disclaimer: The views expressed are purely those of the authors and may not in any circumstances be regarded as an official position of the European Commission.

Appendix A. Selected List of EU Legislation Relevant to the Hydrocarbons Sector in a Historical Order

Note: The below titles are simplified for easy reading, for the authentic version EURLEX shall be consulted. All amendments are not indicated. The pieces in italics are no longer in force. 
1. Directive 67/548 on the classification, packaging and labelling of dangerous substances

2. Directive 68/414 on obligation to maintain minimum stocks of crude oil and/or petroleum products

3. Regulation $1056 / 72 /$ EEC on investment projects in the petroleum, natural gas and electricity sectors

4. Directive $75 / 442$ on waste

5. Directive $76 / 464$ on pollution caused by dangerous substances discharged into aquatic environment

6. Directive $80 / 68$ on the protection of groundwater against pollution caused by dangerous substances

7. Directive $82 / 501$ on the major-accident hazards of certain industrial activities (SEVESO I)

8. Directive $85 / 337$ on assessment of effects of certain public and private projects on the environment

9. Directive 89/391 on measures in the safety and health of workers at work

10. Directive $90 / 531 /$ EEC on the procurement procedures of entities operating in the water, energy, transport and telecommunications sectors

11. Council Resolution on the development of the Community mining industry (OJ C207, 12/08/1989)

12. Regulation 3924/91 on the Community survey of industrial production (PRODCOM List)

13. Directive $91 / 689$ on hazardous waste

14. Directive $92 / 43$ on the conservation of natural habitats and of wild fauna and flora

15. Directive $92 / 91$ concerning the minimum requirements for improving the safety and health protection of workers in the mineral-extracting industries through drilling

16. Directive $93 / 12$ of 23 relating to the sulphur content of certain liquid fuels

17. Directive 94/9 on equipment and protective systems in potentially explosive atmospheres

18. Directive $94 / 22$ on the conditions for granting and using authorizations for the prospection, exploration and production of hydrocarbons

19. Directive $94 / 63$ on the control of volatile organic compound (VOC) emissions resulting from the storage of petrol and its distribution from terminals to service stations

20. Directive 96/29 laying down basic safety standards for the protection of the health of workers and the general public against the dangers arising from ionizing radiation

21. Directive 96/61 concerning integrated pollution prevention and control (IPPC)

22. Directive 1999/31 on the landfill of waste

23. Directive $2000 / 14$ on the noise emission by equipment for use outdoors

24. Directive 2000/60 establishing a framework for Community action in the field of water policy

25. Directive $2000 / 76$ on the incineration of waste

26. Decision 2000/532 establishing a list of waste

27. Decision $2000 / 2850$ on accidental or deliberate marine pollution

28. Directive 2001/42 on assessment of effects of certain plans and programmes on the environment

29. Directive $2001 / 81$ on national emission ceilings for certain atmospheric pollutants

30. Decision 2455/2001 establishing the list of priority substances in the field of water policy

31. Regulation $2150 / 2002$ on waste statistics

32. Directive $2002 / 49$ on the assessment and management of environmental noise

33. Directive $2003 / 4$ on public access to environmental information

34. Directive $2003 / 10$ on the minimum health and safety requirements regarding the exposure of workers to the risks arising from physical agents

35. Directive $2003 / 35$ providing for public participation in respect of the drawing up of certain plans and programmes relating to the environment 
36. Directive $\mathbf{2 0 0 3 / 8 7}$ establishing a scheme for greenhouse gas emission allowance trading

37. Directive 2003/96 on the taxation of energy products and electricity

38. Decision $2003 / 33$ establishing criteria and procedures for the acceptance of waste at landfills

39. Directive $2004 / 35$ on environmental liability with regard to prevention and remedying of environmental damage

40. Directive $2004 / 37$ on protection of workers from risks related to exposure to carcinogens or mutagens at work

41. Directive 2004/107 on arsenic, cadmium, mercury, nickel and polycyclic aromatic hydrocarbons in ambient air

42. Directive 2004/109 on transparency requirements of information about issuers whose securities are admitted to trading on a regulated market

43. Regulation 166/2006 on the European Pollutant Release and Transfer Register

44. Regulation 1893/2006 establishing the statistical classification of economic activities (NACE)

45. Regulation 1907/2006 concerning the Registration, Evaluation, Authorisation and Restriction of Chemicals (REACH), establishing a European Chemicals Agency

46. Directive $2006 / 21$ on the management of waste from extractive industries

47. Directive 2006/32 on energy end-use efficiency and energy services

48. Directive 2006/118 on the protection of groundwater against pollution and deterioration

49. Decision 2006/500 on the Energy Community Treaty

50. Directive 2007/2 on Infrastructure for Spatial Information in the European Community (INSPIRE)

51. Regulation $1099 / 2008$ on energy statistics

52. Regulation $1272 / 2008$ on classification, labelling and packaging of substances and mixtures

53. Directive $2008 / 50$ on ambient air quality and cleaner air

54. Directive 2008/56 establishing a framework for marine environmental policy

55. Directive $2008 / 98$ on waste

56. Directive $\mathbf{2 0 0 8 / 1 1 4}$ on identification and designation of critical infrastructures and assessment of the need to improve their protection

57. Directive 2009/31 on the geological storage of carbon dioxide

58. Directive 2009/73 on common rules for the internal market in natural gas

59. Directive 2009/119 on minimum stocks of crude oil and/or petroleum products

60. Directive 2009/125 on ecodesign requirements for energy-related products

61. Directive 2009/147 on the conservation of wild birds

62. Decision $2009 / 335$ on technical guidelines for the establishment of the financial guarantee concerning the management of waste from extractive industries

63. Decision $2009 / 337$ on the definition of the criteria for the classification of extractive waste facilities

64. Decision 2009/358 on regular transmission of the information and the questionnaire related to the management of waste from extractive industries

65. Decision 2009/359 on the definition of inert extractive waste

66. Decision $2009 / 360$ on the technical requirements for extractive waste characterisation

67. Decision 406/2009 on greenhouse gas emission reduction commitments up to 2020

68. Regulation $617 / 2010$ on the notification on investment projects in energy infrastructure

69. Regulation $994 / 2010$ on measures to safeguard security of gas supply

70. Directive $2010 / 75$ on industrial emissions (integrated pollution prevention and control)

71. Directive 2011/92 on assessment of effects of certain public and private projects on environment

72. Directive 2012/18 on the control of major-accident hazards involving dangerous substances

73. Regulation $347 / 2013$ on guidelines for trans-European energy infrastructure 
74. Directive 2013/30 on safety of offshore oil and gas operations

75. Directive $2013 / 34$ on the annual financial statements of certain types of undertakings

76. Directive $2013 / 59$ on basic safety standards for protection against the dangers arising from exposure to ionising radiation

77. Decision 2013/5 on the Protocol for the Protection of the Mediterranean Sea against pollution resulting from exploration and exploitation of the continental shelf and the seabed and its subsoil

78. Decision 2013/529 on accounting rules on greenhouse gas emissions and removals resulting from activities relating to land use, land-use change and forestry and on information concerned

79. Regulation 256/2014 concerning the notification of investment projects in energy infrastructure

80. Regulation $1112 / 2014$ determining a format for information on major hazard indicators by the operators and owners of offshore oil and gas installations and on major hazard indicators

81. Directive 2014/23 on the award of concession contracts

82. Directive $2014 / 24$ on public procurement

83. Directive $\mathbf{2 0 1 4} / \mathbf{2 5}$ on procurement by entities operating in the water, energy, transport and postal services sectors

84. Directive 2014/89 establishing a framework for maritime spatial planning

85. Directive 2015/1535 on technical regulations and of rules on Information Society services

86. Regulation 2016/1872 establishing for 2016 the 'Prodcom list' of industrial products

87. Directive 2016/943 on the protection of undisclosed know-how and business information (trade secrets) against their unlawful acquisition, use and disclosure

88. Regulation $2017 / 997$ as regards the hazardous property HP 14 'Ecotoxic'

89. Directive $2017 / 845$ on indicative lists of elements to be taken into account for marine strategies

90. Decision 2017/848 laying down criteria and methodological standards on good environmental status of marine waters and specifications and standardised methods for monitoring and assessment

91. Regulation $2017 / 1938$ on measures to safeguard the security of gas supply

92. Regulation 2018/1504 on investment projects in energy infrastructure

93. Regulation 2018/1999 on the Governance of the Energy Union and Climate Action

94. Regulation 2018/2066 on the monitoring and reporting of greenhouse gas emissions

95. Best Available Techniques (BAT) Reference Document for the Management of Waste from Extractive Industries, in accordance with Directive 2006/21/EC; 2018; doi:10.2760/35297

96. Decision $2019 / 708$ on determination of sectors deemed at risk of carbon leakage for 2021-2030

97. Regulation $2019 / 1021$ on persistent organic pollutants

98. Decision $2020 / 248$ on technical guidelines for inspections of extractive waste management facilities

\section{References}

1. International Energy Agency (IAE). European Union Energy Policy Review; IEA: Paris, France, 2020; 310p.

2. Hámor, T. Sustainable mining in the European Union: The legislative aspect. Environ. Manag. 2004, 33, 252-261. [CrossRef] [PubMed]

3. Hámor, T.; Hámor-Vidó, M.; Correia, V. Geology, the regulated discipline and profession in Europe. Episodes 2021, 44, 219-226. [CrossRef]

4. Hámor-Vidó, M.; Hámor, T.; Czirok, L. Underground space: The legal governance of a critical resource in circular economy. Resour. Policy 2021, 73, 102171. [CrossRef]

5. European Commission. Report from the Commission to the Council on Directive 94/22/EC on the Conditions for Granting and Using Authorizations for The prospection, Exploration and Production of Hydrocarbons /COM/98/0447 Final/; European Commission: Brussels, Belgium, 1998. 
6. Tzimas, E.; Georgakaki, A.; Garcia-Cortes, C.; Peteves, E. Enhanced Oil Recovery Using Carbon Dioxide in the European Energy System; EUR 21895 EN 2005, JRC; European Commission: Brussels, Belgium, 2005.

7. Urbaniak, D.; Simon, A.; de Clerck, P.; Fuhr, L.; Jungjohann, A. Shale Gas, Unconventional and Unwanted: The Case against Shale Gas Extractive Industries: Blessing or Curse? Friends of the Earth Europe, Heinrich Böll Foundation: Berlin, Germany, 2012; 32p.

8. European Parliament. Resolution of 21 November 2012 on the Environmental Impacts of Shale Gas and Shale Oil Extraction Activities (2011/2308(INI)); European Parliament: Brussels, Belgium, 2012.

9. European Economic and Social Committee (EESC). On the "Communication from the Commission to the European Parliament, the Council, the European Economic and Social Committee and the Committee of the Regions on the Exploration and Production of Hydrocarbons (Such as Shale Gas) Using High Volume Hydraulic Fracturing in the EU" COM(2014) 23 Final (2014/C 424/05); EESC: Brussels, Belgium, 2014.

10. European Commission. Final Report on Unconventional Gas in Europe-Philippe E Partners, Brussels, Service Contract for Legal Assistance TREN/R1/350-2008 lot 1; European Commission: Brussels, Belgium, 2011; 104p.

11. European Commission. Impacts of Shale Gas and Shale Oil Extraction on the Environment and on Human Health; European Commission: Brussels, Belgium, 2011.

12. European Commission. Unconventional Gas: Potential Energy Market Impacts in the European Union; European Commission: Brussels, Belgium, 2012; 328p.

13. European Commission. Technical Support for the Risk Management of Unconventional Hydrocarbon Extraction; Amec \& Foster \& Wheeler: Bristol, UK, 2015; pp. 181p.

14. Broomfield, L.; Lelland, A. Support to the Identification of Potential Risks for the Environment and Human Health Arising from Hydrocarbons Operations Involving Hydraulic Fracturing in Europe-Report for European Commission DG Environment AEA/R/ED57281 Issue Number 11, Oxfordshire; AEA: Arnhem-Nijmegen, The Netherlands, 2012; 292p.

15. Kpmg Global Energy Institute. Central and Eastern European Shale Gas Outlook; Kpmg Global Energy Institute: Budapest, Hungary, 2012; 98p.

16. Forster, D.; Perks, J. Climate Impact of Potential Shale Gas Production in the EU-Report for European Commission DG CLIMA AEA/R/ED57412 Issue 2, Oxfordshire; AEA: Arnhem-Nijmegen, The Netherlands, 2013; 149p.

17. Umweltbundesamt (UBA). Environmental Impacts of Fracking Related to Exploration and Exploitation of Unconventional Natural Gas Deposits. Risk Assessment, Recommendations for Action and Evaluation of Relevant Existing Legal Provisions and Administrative Structures; UBA: Lagos, Nigeria, 2013.

18. Ballesteros, M.; Pelsy, F.; Reins, L. Regulatory Provisions Governing Key Aspects of Unconventional Gas Extraction in Selected EU Member States; 070307/2012/630593/SER/ENV.F1; Milieu Ltd.: Brussels, Belgium, 2012.

19. Amec Foster Wheeler. Study on the Assessment and Management of Environmental Impacts and Risks from Exploration and Production of Hydrocarbons; European Commission: Luxembourg, 2016; 412p.

20. Mitchell, D.; Spörker, T.; Machetanz, K.; Posselt, J.P.; Danvers, C.; Diop, Y.; Hámor, T.; Papp, Z.; Abdoellakhan, I.; McAllister, N.; et al. Best Practice in Regulating Onshore Oil and Gas Operations (Including Shale Gas)_IMPEL Report No. 2015/03; Brussels, Belgium, 2016; 26p, Available online: https:/ /www.impel.eu/wp-content/uploads/2016/06/FR-2015-03-Onshore-Oil-and-GasProject.pdf (accessed on 4 October 2021).

21. Durling, J.; Spörker, T.; Posselt, J.P.; Danvers, C.; Limet, F.; Ferket, H.; Diop, Y.; Trombitás, P.; Bányácski, S.; Hamor, T.; et al Onshore Oil and Gas Regulation-Phase II-2016, Sharing Regulatory Best Practice in Regulating the Exploration and Production of the Onshore Oil and Gas Industry, Including Unconventional Fossil Fuels and High-Volume Hydraulic Fracturing-IMPEL Report No. 2016/01; Brussels, Belgium, 2017; 33p, Available online: https:/ /www.impel.eu/wp-content/uploads/2018/01/FR-2016-01Onshore-Oil-and-Gas-Regulation.pdf (accessed on 4 October 2021).

22. European Commission. Communication from The Commission To The European Parliament, The Council, The European Economic and Social Committee and the Committee of the Regions on the Exploration and Production of Hydrocarbons (Such as Shale Gas) Using High Volume Hydraulic Fracturing in the EU /COM/2014/023 Final/2/, \{SWD(2014) 21 Final\} \{SWD(2014) 22 Final\}; European Commission: Brussels, Belgium, 2014.

23. European Commission. Recommendation of 22 January 2014 on Minimum Principles for the Exploration and Production of Hydrocarbons (Such as Shale Gas) Using High-Volume Hydraulic Fracturing (2014/70/EU); European Commission: Brussels, Belgium, 2014.

24. European Commission. Report from the Commission to the European Parliament and the Council on the Effectiveness of Recommendation 2014/70/EU on Minimum Principles for the Exploration and Production of Hydrocarbons (Such as Shale Gas) Using High-Volume Hydraulic Fracturing, 15.12.2016, COM(2016) 794 Final; European Commission: Brussels, Belgium, 2016; 11p.

25. European Commission. Communication from the Commission to the European Parliament and the Council-The Raw Materials Initiative: Meeting Our Critical Needs for Growth and Jobs in Europe \{SEC(2008) 2741\}/COM/2008/0699/; European Commission: Brussels, Belgium, 2008.

26. European Commission. Communication from The Commission-Making Raw Materials Available For Europe's Future Well-Beingproposal for a European Innovation Partnership on Raw Materials /COM/2012/082/; European Commission: Brussels, Belgium, 2012.

27. Christman, P.; Diercks, T.; Marlet, C.; Drielsma, J.; Hebestreit, C.; Wyart-Remy, M.; Goffeaux, N.; de Visscher, F.; Fincke, D.; Schulz, M.; et al. Recommendations on the Framework Conditions for the Extraction of Non-Energy Raw Materials in the European Union-Report of the Ad Hoc Working Group on Exchange of Best Practices in Minerals Policy and Legal Framework, Information Framework, Land-Use Planning and Permitting; European Commission: Brussels, Belgium, 2014; 35p. 
28. European Commission. Legal Framework for Mineral Extraction and Permitting Procedures for Exploration and Exploitation in the EU; European Commission: Brussels, Belgium, 2017; 42p.

29. Matláry, J.H. Energy Policy in the European Union; Macmillan Publishers Limited, Palgrave: London, UK, 1997.

30. Li, G.; Bai, X.; Huo, S.; Huang, Y. Fast pyrolysis of LERDADEs for renewable biofuels. IET Renew. Power Gener. 2020, 14, 959-967. [CrossRef]

31. Li, G.; Lu, Z.; Zhang, J.; Li, H.; Zhou, Y.; Zayan, A.M.I.; Huang, Z. Life cycle assessment of biofuel production from microalgae cultivated in anaerobic digested wastewater. Int. J. Agric. Biol. Eng. 2020, 13, 241-246. [CrossRef]

32. Hámor, T.; Vidal-Legaz, B.; Zampori, L.; Eynard, U.; Pennington, D. Background Study on the Environmental Impact Assessment of Non-Energy Minerals Extraction Projects with Regard to European Union Community Requirements, JRC Technical Report; Publications Office of the European Union: Ispra, Italy, 2021; 200p, ISBN 978-92-76-38988-0.

33. Goertz-Allmann, B.P.; Goertz, A.; Wiemer, S. Stress drop variations of induced earthquakes at the Basel geothermal site. Geophys. Res. Lett. 2011, 38. [CrossRef]

34. Soltani, M.; Kashkooli, F.M.; Souri, M.; Rafiei, B.; Jabarifar, M.; Gharali, K.; Nathwani, J.S. Environmental, economic, and social impacts of geothermal energy systems. Renew. Sustain. Energy Rev. 2021, 140, 110750. [CrossRef]

35. European Commission. Commission Staff Working Document Fitness Check: Reporting, Planning and Monitoring Obligations in the EU Energy Acquis, Accompanying the document to Proposal for a Regulation of the European Parliament and of the Council on the Governance of the Energy Union \{COM(2016) 759 Final\} \{SWD(2016) 396 Final\}, SWD(2016) 397 Final; European Commission: Brussels, Belgium, 2016.

36. Püspöki, Z.; Debreczeni, Á.; Fancsik, T.; Hámorné Vidó, M.; Zelei, G. (Eds.) Coal Resources and Utilization Perspectives of Hungary; Mining and Geological Survey of Hungary: Budapest, Hungary, 2018; 280p. 